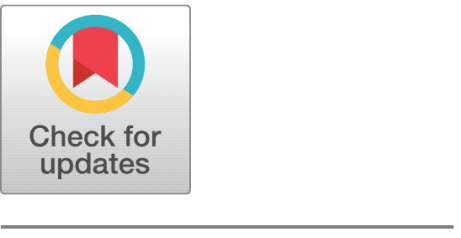

OPEN ACCESS

Received: 25.11 .2020

Accepted: 11.06 .2021

Published: 02.07 .2021

Citation: Sundar ML, Muthukeerthana S, Ezhilarasan G (2021) Behaviour of Concrete Filled Double Skin (CFDS) Steel Tube by Partial Replacement of Coarse Aggregate with Brickbats. Indian Journal of Science and Technology 14(22): 1894-1904. https://doi.org/ 10.17485/IJST/v14i22.2087

* Corresponding author.

m.leninsundar@skct.edu.in

Funding: None

Competing Interests: None

Copyright: ๑ 2021 Sundar et al. This is an open access article distributed under the terms of the Creative Commons Attribution License, which permits unrestricted use, distribution, and reproduction in any medium, provided the original author and source are credited.

Published By Indian Society for Education and Environment (iSee)

ISSN

Print: 0974-6846

Electronic: 0974-5645

\section{Behaviour of Concrete Filled Double Skin (CFDS) Steel Tube by Partial Replacement of Coarse Aggregate with Brickbats}

\author{
M Lenin Sundar ${ }^{1 *}$, S Muthukeerthana ${ }^{2}$, G Ezhilarasan ${ }^{3}$ \\ 1 Professor, Department of Civil Engineering, Sri Krishna College of Technology, Coimbatore, \\ 641042, Tamil Nadu, India \\ 2 Assistant professor, Department of Civil Engineering, Sri Krishna College of Technology, \\ Coimbatore, 641042, Tamil Nadu, India \\ 3 Post Graduate student, Department of Civil Engineering, Sri Krishna College of Technology, \\ Coimbatore, 641042, Tamil Nadu, India
}

\section{Abstract}

Objectives: To find the optimum percentage replacement of brickbats in concrete by performing fresh and hardened concrete tests and is incorporated into CFDS steel tube column to study its behaviour analytically. Methods: The behaviour of a double skin CFST column with brickbats partially substituting the coarse material with Brickbats. Part of the coarse aggregate was replaced with grouted class I brick bats with percentages of 5 to $25 \%$. A study of the compressive and split tensile strength of concrete was conducted fresh and hardened tests on concrete specimens (cubes and cylinders). Performance of CFDS steel tube column partially replacing coarse aggregate with brickbats is examined analytically using ANSYS. Findings: The compressive and split tensile strength of 10 percent replacement brickbats improved by 8.5 and 13 percent, respectively, while the compressive and split tensile strength of 5 percent replacement brickbats increased by 1.67 and 6 percent, respectively. When compared to nominal cube strength, partially replace brickbats compressive strength increases gradually up to $10 \%$ brickbat replacement and then tends to decrease from 15percent brickbat replacement. When compared to different mixtures, it was discovered that adding $10 \%$ brickbats increases strength, and this amount was deemed the best mix proportion. The highest load taken by CFDS with $10 \%$ brickbats is $649.36 \mathrm{kN}$, whereas standard CFDS is $705.16 \mathrm{kN}$. The CFDS tube was replaced by CFDS tube, which took 1.15 percent more load than brick bats. Novelty/Applications: This research yields good result and can be adopted for the construction of tall composite buildings. This technique will be reduced the self - weight of the structure to some extent.

Keywords: CFDS; brickbats; concrete; confinement effect; ANSYS 


\section{Introduction}

Concrete filled double skin (CFDS) steel tube columns are important structural elements in composite development. CFDS exists in different shapes, for example, rectangular, circular, trapezoidal etc. CFDS columns are efficient and faster to develop when compared to conventional concrete because they don't need any kind of framework during construction it can be prefabricated as per the structural requirements. In the field of steel and solid composite development, Concrete Filled double skin (CFDS) steel tube segments have been checked to be extraordinary individuals ${ }^{(1)}$. Concrete filled double skin steel tube (CFDS) segments consist of two concentrically placed steel segments and the gap between the segments loaded up with concrete $^{(2-4)}$. Since the previous studies carried out using concrete as filling material in CFDS this study is planned to be loaded concrete into CFDS steel tube column that partially replaces the coarse aggregate with brickbats. In the present study, optimum percentage replacement of brickbats in concrete is identified by performing fresh and hardened concrete tests and is incorporated into CFDS steel tube column this replacement is done to reduce the self-weight of the structural elements.

Load carrying capacity and lateral deflection of the CFDS steel tube was investigated ${ }^{(5)}$. Although there is no specific design for CFDS steel tube, Author designed the steel tube on the basis of strength super position method and arrived the deflection for the corresponding load applied. A study on behaviour of CFDS steel tube with different cross section for outer and inner tube (Circular Hollow Section CHS outer and Square hollow Sections SHS inner) was carried out ${ }^{(6,7)}$. In this study stub column is designed and annulus of the column is filled with high strength concrete and tested for the axial compression behaviour. An experimental study on circular CFDS steel tube was studied ${ }^{(8)}$. In this study totally 32 number of circular tubes were tested in various cross section, particularly the outer circular steel tube size and thickness is varied and all the specimen is tested for overall buckling. An experimental study on behaviour of CFDS steel tubular beam and column conducted ${ }^{(9)}$. These CFDS beam-column is made of cold formed steel with different cross section and its test results are compared with the conventional beam-column. Load carrying capacity of both CFDS steel tube and conventional beam-column is observed ${ }^{(10)}$.

A study was carried out ${ }^{(11)}$ on Analytical behaviour of CFDST circular stub column. Finite element model is created and its sectional capacity is checked. The results obtained are compared with data reported by different researches. A study on (Fundamentals of Engineering FE) modelling and fire resistance design of CFDS steel tube was conducted ${ }^{(12)}$. Thermal and structural response of the FE model under the fire exposure is observed in this study ${ }^{(13)}$. What are the parameters that are affected by thermal effect is noted in order to improve the structural stability towards fire.

Lightweight aggregate incorporated in (concrete filled steel tubes) CFST column in order to reduce the self-weight of the column was studied ${ }^{(14)}$. All the fresh concrete test is made in order to confirm the properties of the concrete as per the Indian standards. The circular (concrete filled steel tubes) CFST incorporated with lightweight aggregate is tested for the axial compression behaviour. An investigation on brickbats and steel fiber incorporated Self Compacting Concrete in order to find the behaviour of the concrete on addition brickbats and steel fiber conducted ${ }^{(15)}$. In order to maintain the workability of concrete super plasticizer is used ${ }^{(16)}$. This SCC is used in (concrete filled steel tubes) CFST column to find its compression and split tensile strength. Crushed and over burnt brick as an alternate for coarse aggregate was investigated ${ }^{(17)}$. To find out the suitability of crushed and over burnt brick as coarse aggregate their properties such as crushing value, impact value and water absorption are carried out and concrete cubes are made with this over burnt bricks tested for compression value ${ }^{(18)}$. Incorporating waste materials such as ceramic tiles, ceramic insulator and broken glass pieces as a replacement for coarse aggregate was examined ${ }^{(19)}$. To find out the strength parameters of the concrete that is made with these waste materials cubes are casted and tested for compression and split tensile value.

\section{Materials and Methods}

\subsection{Cement}

Ordinary Portland cement (OPC) of 53 grades available in market was used in investigation. The cement used has been tested for various proportions as per IS:4031:1988. Grade 53 indicate that the cement will attain a compressive strength of $53 \mathrm{~N} / \mathrm{mm}^{2}$ area after curing period of 28 days. Specification for Ordinary Portland Cement ${ }^{(20)}$ [Table 1 ]. 
Table 1. Test on Cement

\begin{tabular}{ll}
\hline Test & Results \\
\hline Specific gravity of cement & 3.2 \\
Fineness of cement & 9 \\
10 Consistency of Cement & 31 percent \\
Initial Setting time of Cement & $30 \mathrm{Min}$ \\
\hline
\end{tabular}

\subsection{Fine aggregate ( $M$ - SAND)}

Manufactured sand (M-Sand) is used as a substitute for river sand. They are produced by crushing hard granite rocks into fine powder and used as fine aggregate. In this project well processed M-sand is used as fine aggregate and results are shown in IS:383:1970 specifications for fine aggregate ${ }^{(21)}$ [Table ??].

Table 2. Test on Fine Aggregate

\begin{tabular}{ll}
\hline Test & Results \\
\hline Specific gravity of fine aggregate & 2.47 \\
Fineness of fine aggregate & 3.32 \\
\hline
\end{tabular}

\subsection{Coarse aggregate}

Coarse aggregate of size $20 \mathrm{~mm}$ is used here. As per ${ }^{(22)}$ the entire basic test required to determine the character (i.e. Water absorption, crushing value, impact test) of the coarse aggregate is done and the test results are given in IS:383:1970 specifications for coarse aggregate ${ }^{(21)}$ [Table 3 ].

Table 3. Test on Coarse Aggregate

\begin{tabular}{ll}
\hline Test & Results \\
\hline Specific gravity of Coarse aggregate & 2.71 \\
Impact value & 22.04 percent \\
Crushing value & 39.2 percent \\
\hline
\end{tabular}

\subsection{Brickbats}

Brick bats are nothing but over burnt bricks that are left as waste or demolition waste. The unit of brick aggregate concrete is less than stone aggregates. The use of mix of brick aggregate and stone aggregate improves the strength and stiffness of concrete. The use of aggregate reduces the wastage and helps in the preservation of natural aggregate resources. In this project, brickbat of size $10 \mathrm{~mm}$ to $20 \mathrm{~mm}$ is used. The results of the specific gravity, impact test and water absorption test are presented in SP 20-1991 [Table 4 ].

Table 4. Test on Brickbats

\begin{tabular}{ll}
\hline Test & Results \\
\hline Specific gravity of Coarse aggregate & 2.45 \\
Impact value & 28.2 percent \\
Water absorption & 6.7 percent \\
\hline
\end{tabular}

\subsection{Cold Formed Steel}

The ultimate tensile strength is determined by conducting a Coupon test on a cold formed steel specimen to determine parameters that are directly quantified by a tensile test. The specimens of $2 \mathrm{~mm}$ and $3 \mathrm{~mm}$ thick are used before and after the test are shown in [Figures 1 and 2].The results obtained are shown inIS 811 (1987): Cold Formed Light Gauge Structural Steel[Table ??]. 


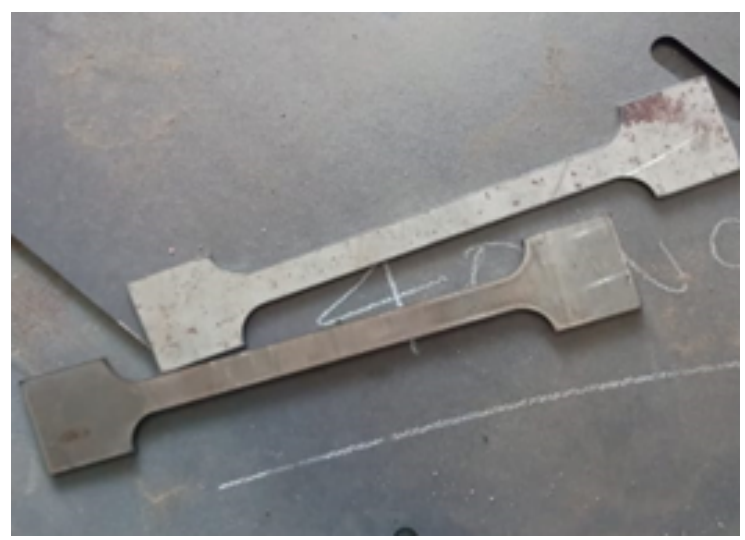

Fig 1. Cold Formed Steel Specimen before Coupon Test

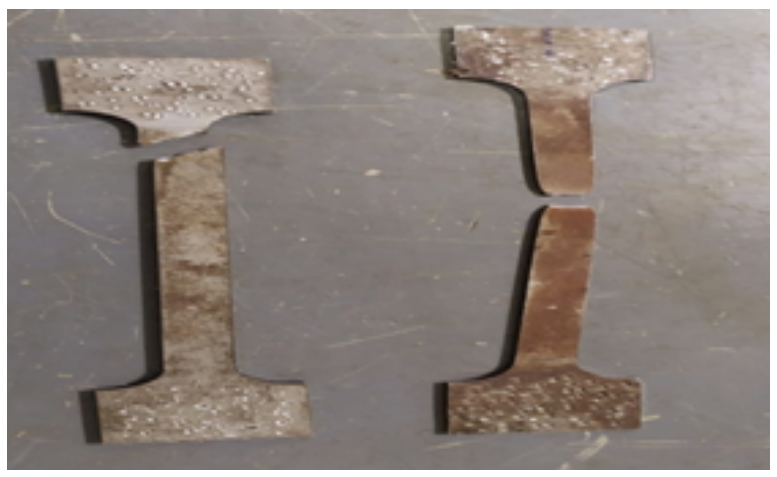

Fig 2. Cold Formed SteelSpecimen after Coupon Test

Table 5. Coupon Test Results

\begin{tabular}{ll}
\hline Thickness & Ultimate load carrying capacity \\
\hline $2 \mathrm{~mm}$ & $11.75 \mathrm{kN}$ \\
$3 \mathrm{~mm}$ & $31.21 \mathrm{kN}$ \\
\hline
\end{tabular}

\subsection{Water}

Concrete can usually be made with water that is safe to drink. Acids, oils, alkalis, and organic contaminants should all be removed from the water.

\subsection{Mix Design}

The mix design details for $1 \mathrm{~m} 3$ of concrete with partially replaced coarse aggregate with brickbats are given in IS 10262:2009[Tables 6 and 7 ].

Table 6. Weight of Materials per $\mathrm{m}^{3}$ (M20)

\begin{tabular}{llll}
\hline $\begin{array}{l}\text { Water } \\
(\mathrm{kg} / \mathrm{m} 3)\end{array}$ & $\begin{array}{l}\text { Cement } \\
(\mathrm{kg} / \mathrm{m} 3)\end{array}$ & $\begin{array}{l}\text { Fine aggregate } \\
(\mathrm{kg} / \mathrm{m} 3)\end{array}$ & $\begin{array}{l}\text { Coarse aggregate } \\
(\mathrm{Kg} / \mathrm{m} 3)\end{array}$ \\
\hline 197.2 & 438 & 609 & 1133 \\
0.45 & 1 & 1.46 & 2.56 \\
\hline
\end{tabular}


Table 7. Percentage of Replacement of Brickbats

\begin{tabular}{lll}
\hline Percentage replacement of brickbats & $\begin{array}{l}\text { Nominal coarse aggregate } \\
(\mathrm{kg} / \mathrm{m} 3)\end{array}$ & $\begin{array}{l}\text { Brickbats } \\
(\mathrm{kg} / \mathrm{m} 3)\end{array}$ \\
\hline 5 & 1098 & 33 \\
10 & 1040 & 93 \\
15 & 934 & 199 \\
20 & 879 & 254 \\
25 & 850 & 283 \\
\hline
\end{tabular}

\subsection{Methodology}

The methodology adopted for this study was explained in [Figure 3].

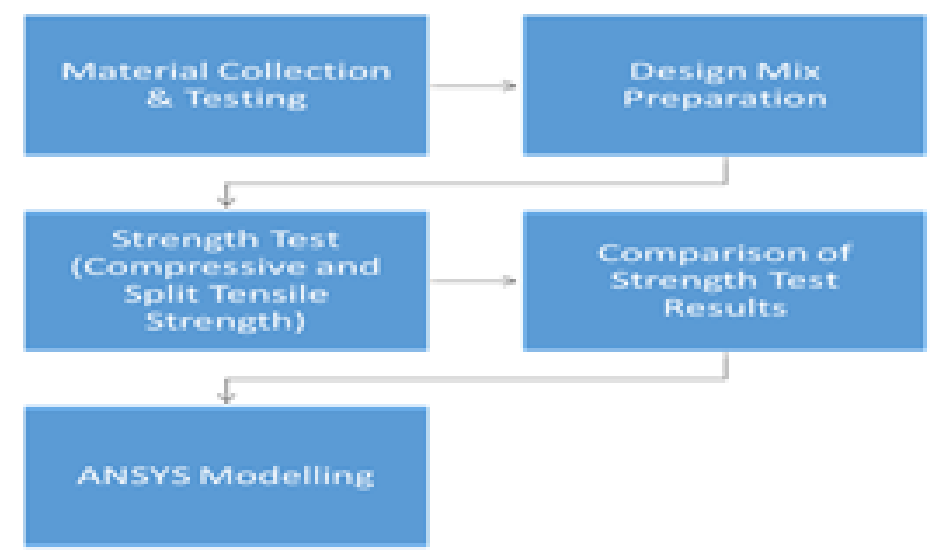

Fig 3. Methodology Flow Chart

\subsection{Experimental Investigation}

\subsubsection{Slump Cone Test}

Slump test was conducted to determine the workability of fresh concrete produce with brickbats. Concrete mix was prepared by replacing brickbats with 5, 10,15, 20 and 25 percent by volume. The slump was determined with help of slump cone apparatus in accordance with ${ }^{(23)}$ and the results are presented in [Table 8 ] and it can be concluded that the slump of brickbats aggregate concrete decreases with increase in percentage of replacement. The lower workability of concrete at high replacement may be attributed due to higher water absorption. So the w/c ratio is to increase for better workability.

\begin{tabular}{ll}
\multicolumn{2}{c}{ Table 8. Slump Values } \\
\hline M20Grade Concrete & Slump Value $(\mathrm{mm})$ \\
\hline Control Mix & 100 \\
BB 5 percent & 100 \\
BB 10 percent & 96 \\
BB 15 percent & 95 \\
BB 20 percent & 87 \\
BB 25 percent & 82 \\
\hline
\end{tabular}

\subsubsection{Compression test on concrete}

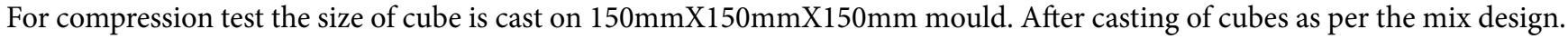
The cubes are cured for 28 days to reach their maximum strength. After the curing process the cubes are dried for 24 hours in room temperature for compression test. After the drying process the cube is tested in compression testing machine. Before 
placing the cube the surface of the machine should be cleaned there should not be any obstruction. Then the cube is placed and the load gradually applied without shock and continuously at the rate of $5.2 \mathrm{kN} / \mathrm{sec}$ till the specimen fails. The maximum load recorded and any unusual features in the type of failure noted down. It is carried out for both 7 and 28 days specimen and results are presented inIS 516:1959 'Method of test for strength of concrete. [Table 9 ] and [Figure 4].

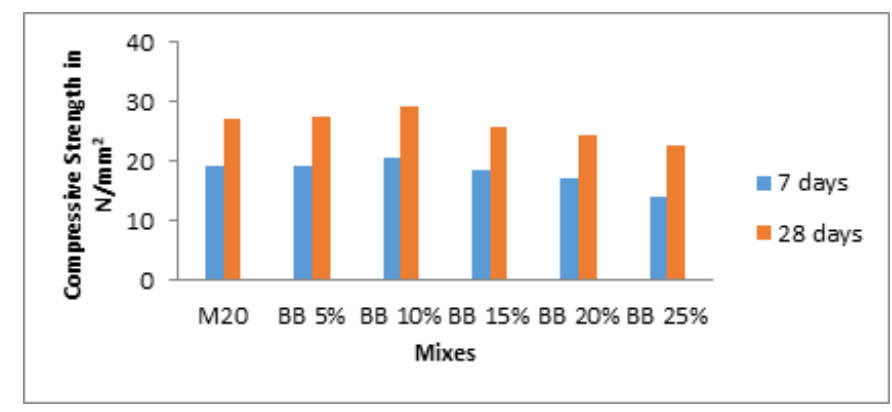

Fig 4. Compressive Strength Test Results

Table 9. Compression Test Results

\begin{tabular}{lll}
\hline Description & $\begin{array}{l}\text { Compressive strength 7 days } \\
(\mathrm{N} / \mathrm{mm} 2)\end{array}$ & $\begin{array}{l}\text { Compressive strength 28 days } \\
(\mathrm{N} / \mathrm{mm} 2)\end{array}$ \\
\hline M20 & 19.11 & 27 \\
5 percent & 13.28 & 27.45 \\
10 percent & 20.53 & 29.30 \\
15 percent & 19.39 & 25.71 \\
20 percent & 17.10 & 24.26 \\
25 percent & 14.49 & 22.67 \\
\hline
\end{tabular}

\subsubsection{Split tensile strength on concrete}

Splitting tensile strength is done to evaluate tensile strength of the respective grade of concrete. For split tensile test cylinder specimen of size having height of $100 \mathrm{~mm}$ and diameter of $150 \mathrm{~mm}$ is casted as per the mix design and cured for 7 and 28 days. After the curing process it is dried for $24 \mathrm{hrs}$ and tested. Before placing the cylinder specimen in the machine surface two steel plate is placed at top and bottom surface of the cylinder specimen for uniform distribution of load on the surface of the cylinder. The Split tensile strength tests are carried out at 7 and 28 days for the cylindrical specimen using compressive testing machine of $2000 \mathrm{kN}$ according to ${ }^{(1)}$ and the results are given in [Table 10 ]. The load is applied slowly till the specimens split and readings are noted. [Figure 5] shows the split tensile strength test results ${ }^{(24)}$.

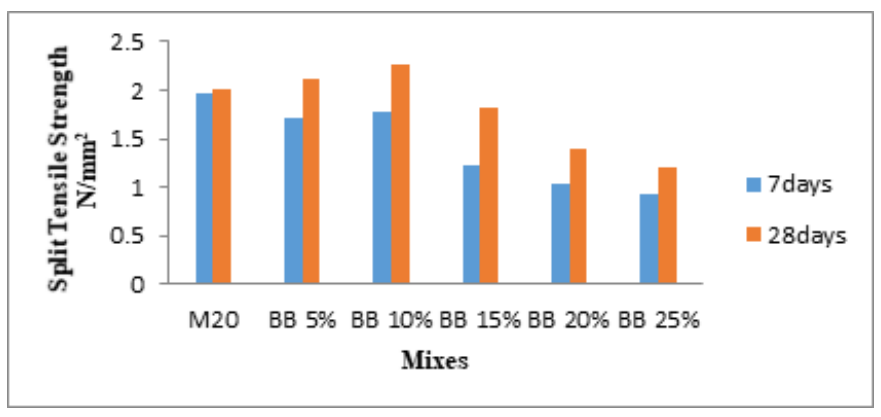

Fig 5. Split Tensile Strength Test Result 
Table 10. Split Tensile Strength Test Results

\begin{tabular}{lll}
\hline Description & $\begin{array}{l}\text { Split tensile strength 7 days } \\
(\mathrm{N} / \mathrm{mm} 2)\end{array}$ & $\begin{array}{l}\text { Split tensile strength 28 days } \\
(\mathrm{N} / \mathrm{mm} 2)\end{array}$ \\
\hline M20 & 1.69 & 2 \\
5 percent & 1.71 & 2.12 \\
10 percent & 1.78 & 2.26 \\
15 percent & 1.23 & 1.82 \\
20 percent & 1.04 & 1.40 \\
25 percent & 0.92 & 1.21 \\
\hline
\end{tabular}

\subsection{Finite Element Analysis of CFDS Steel Tube Columns}

Finite Element Analysis (FEA) uses mathematical models to understand and quantify the effects of real-world conditions on a part or assembly. These simulations, which are conducted via specialized software, allow engineers to locate potential problems in a design, including areas of tension and weak spots. ${ }^{(25)}$

Static Structural analysis is adopted for this study. The material property of concrete and steel are explained here. The grade of concrete used to fill the steel is M20.

\subsubsection{Engineering Data}

The material property of concrete and steel are explained here. The grade of concrete used to fill the steel is M20. The engineering data used is given in [Table 11 ].

Table 11. Engineering Data

\begin{tabular}{lllll}
\hline Data & $\begin{array}{l}\text { Density } \\
\mathrm{kg} / \mathrm{m} 3\end{array}$ & $\begin{array}{l}\text { Young's modulus X 103 } \\
\mathrm{N} / \mathrm{mm} 2\end{array}$ & $\begin{array}{l}\text { Poisson's } \\
\text { ratio }\end{array}$ & Size \\
\hline $\begin{array}{l}\text { Concrete with } 10 \text { percent } \\
\text { brickbat }\end{array}$ & 2625 & 2.03 & 0.3 & $\mathrm{Bi}=45 \mathrm{~mm}$ \\
& & & $\begin{array}{l}\mathrm{Bo}=100 \mathrm{~mm} \\
\mathrm{Di}=75 \mathrm{~mm}\end{array}$ \\
& & & $\mathrm{Do}=150 \mathrm{~mm}$ \\
& & & $\mathrm{TK}=2 \mathrm{~mm}$ \\
CFDS steel tube & 2 & 0.3 & $\mathrm{Bi}=45 \mathrm{~mm}$ \\
& & & $\mathrm{Bo}=100 \mathrm{~mm}$ \\
& & & $\mathrm{Di}=75 \mathrm{~mm}$ \\
& & & $\mathrm{Do}=150 \mathrm{~mm}$ \\
& & & $\mathrm{TK}=2 \mathrm{~mm}$ \\
\hline
\end{tabular}

\subsubsection{Geometry}

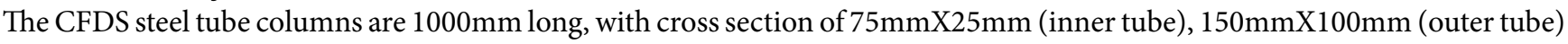
and thickness of steel tube is $2 \mathrm{~mm}$.

\subsubsection{Modelling}

A total of 2 CFDS steel tube columns are modelled. In this, one model is control specimen, i.e. column without brickbats and another one is column with brickbats. The model used for this study is as shown in [Figure 6].

\subsubsection{Meshing}

Meshing is nothing but discretization of continuous body into finite number of elements. A mesh size of $25 \mathrm{~mm}$ is provided for all CFDS steel tube column of this study.

\subsubsection{Analysis}

In this analysis static structure of nonlinear buckling analysis is considered. Static structural analysis gives different types of stress, strain and deformation of particular element. Axial loads and supports are assigned to the column and deformation, stress and force reaction are obtain from ANSYS workbench. 


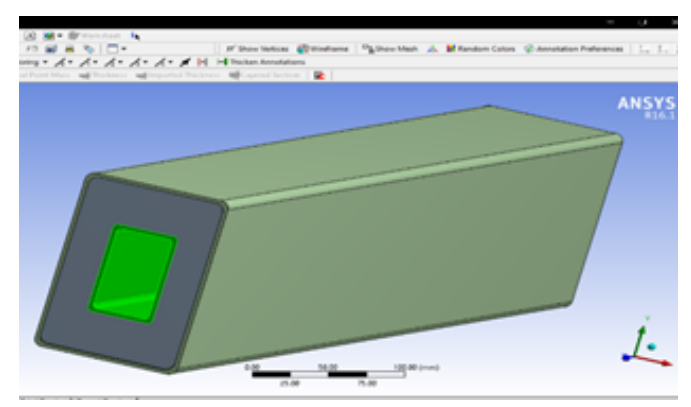

Fig 6. Model of CFDS Steel Tube Column

\section{Results and Discussion}

When comparing the five proportions of brickbats as coarse material that has been partially replaced. According to the findings [Figures 4 and 5], the compressive and split tensile strength of 10 percent replacement brickbats improved by 8.5 and 13 percent, respectively, while the compressive and split tensile strength of 5 percent replacement brickbats increased by 1.67 and $6 \%$, respectively. When compared to nominal cube strength, partially replace brickbats compressive strength increases gradually up to $10 \%$ brickbat replacement and then tends to decrease from $15 \%$ brickbat replacement. In comparison to other percentages and nominal mixes, the ideal proportion of brickbats substitution in concrete is $10 \%$, which provides great strength. As a result, coarse aggregate will be partially replaced with $10 \%$ brickbats in this study, and it will be assimilated in a CFDS steel tube column for finite element analysis. From [Figures 7 and 8], it is clear that the total deformation of CFDS steel column is more or less similar in control specimen and in specimen with brickbats.

It have been evident that, both the principle stress and shear stress is minimum in controlled mix when compared to column with brickbats [Figures 9, 10, 11 and 12 ].

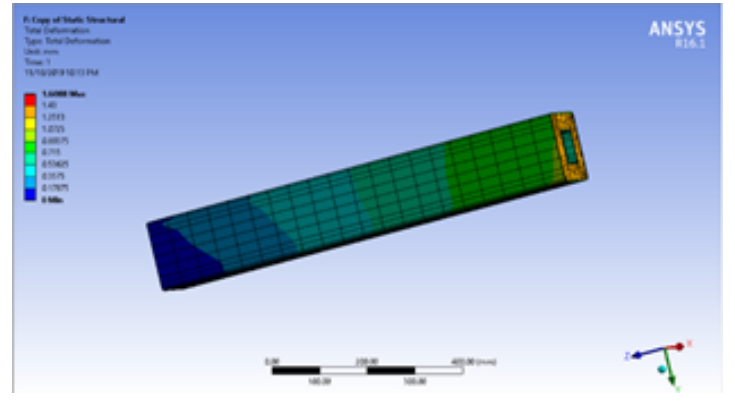

Fig 7. Total Deformation (Control Specimen)

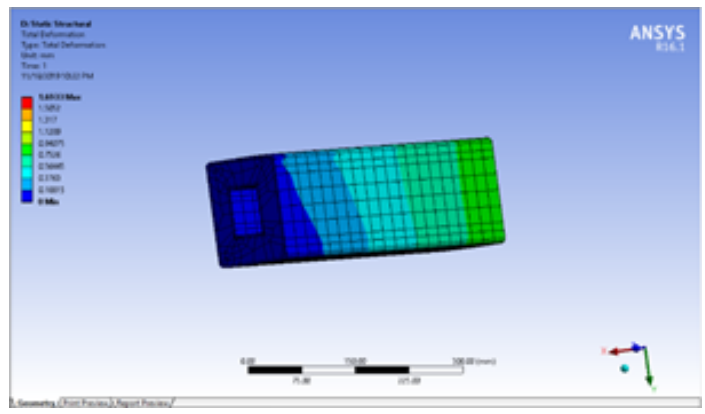

Fig 8. Total Deformation (with Brickbats) 


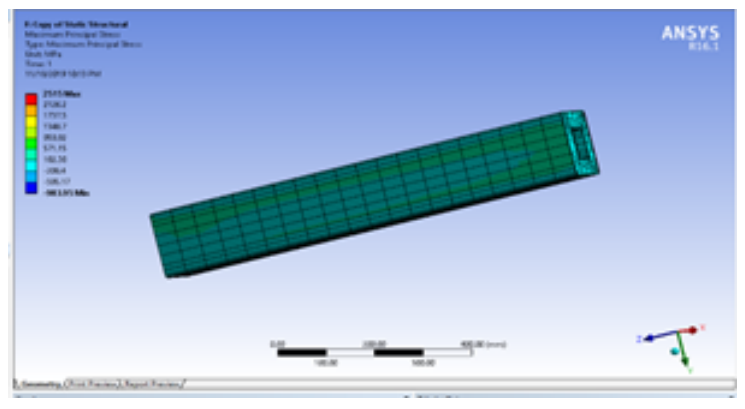

Fig 9. Principle Stress (Control Specimen)

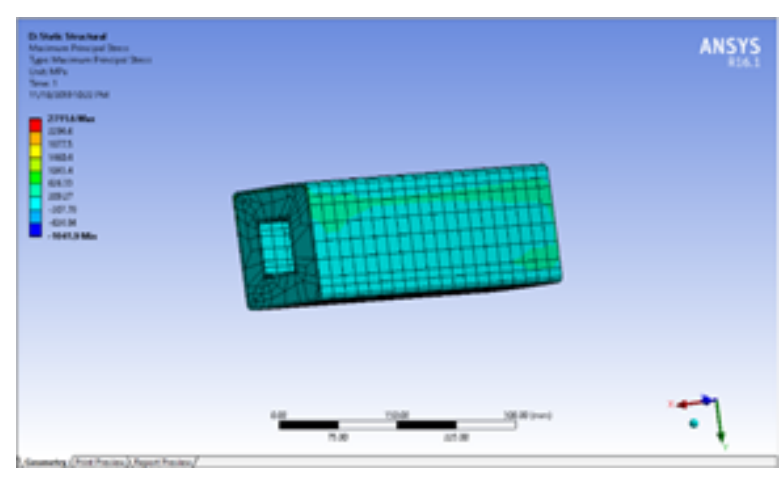

Fig 10. Principle Stress (with Brickbats)

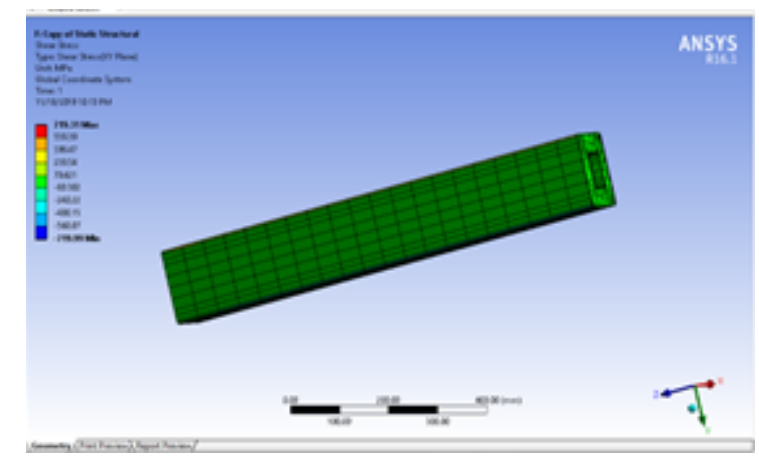

Fig 11. Shear Stress (Control Specimen)

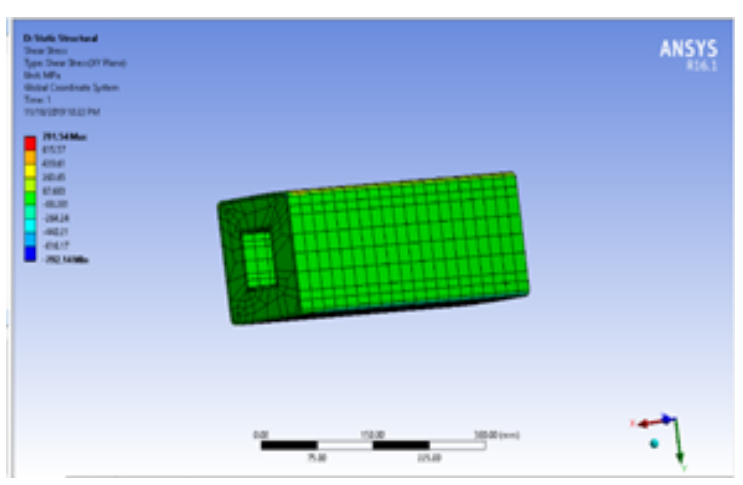

Fig 12. Shear Stress (with Brickbats) 


\section{Conclusion}

It is clear from this research that brickbats, which are waste by-products of building and demolition detritus, can be employed as aggregates in CFDS tubes. Brickbats are made by shredding bricks to a size of 10 to $20 \mathrm{~mm}$ and mixing them in various amounts of $5,10,15,20$, and $25 \%$. Despite the fact that brickbats are a lower-quality material than standard aggregates when used in CFDS tubes, they produce appropriate compressive and split tensile strength by using optimal mix proportions determined through experimental analysis. When compared to different mixtures, it was discovered that adding $10 \%$ brickbats increases strength, and this amount was deemed the best mix proportion. The highest load taken by CFDS with $10 \%$ brickbats is $649.36 \mathrm{kN}$, whereas standard CFDS is $705.16 \mathrm{kN}$. The CFDS tube was replaced by CFDS tube, which took 1.15 percent more load than brick bats. Also, the principal and shear stresses are minimum in controlled mix when compared to brick bats column. This study has produced positive results, which can be used to construct tall composite buildings. The structures self-weight will be lowered to some extent if this strategy is used. This opens the door to more experimental testing of composite elements like CFDS columns to confirm the analytical conclusions.

\section{References}

1) Chen J, Wang J, Xie F, Duan A. Behavior of thin-walled dodecagonal section double skin concrete-filled steel tubular beam-columns. Thin-Walled Structures. 2016;104:135-143. Available from: https://dx.doi.org/10.1016/j.tws.2016.03.008.

2) Ekmekyapar T. Experimental performance of concrete filled welded steel tube columns. Journal of Constructional Steel Research. 2016;117:175-184. Available from: https://dx.doi.org/10.1016/j.jcsr.2015.10.013.

3) Ekmekyapar T, AL-Eliwi BJM. Experimental behaviour of circular concrete filled steel tube columns and design specifications. Thin-Walled Structures. 2016;105:220-230. Available from: https://dx.doi.org/10.1016/j.tws.2016.04.004.

4) Han LH, Li W, Bjorhovde R. Developments and advanced applications of concrete-filled steel tubular (CFST) structures: Members. Journal of Constructional Steel Research. 2014;100:211-228. Available from: https://dx.doi.org/10.1016/j.jcsr.2014.04.016.

5) M SU, A JS. Axial Compression Behaviour of Long Concrete Filled Double Skinned Steel Tubular Columns. Structures. 2017;9:157-164. Available from: https://dx.doi.org/10.1016/j.istruc.2016.12.002.

6) Elchalakani M, Zhao XL, Grzebieta RH. Tests on concrete filled double-skin (Circular Hollow Section CHS outer and Square hollow Sections SHS inner) composite short columns under axial compression. Thin-Walled Structures. 2002;40(5):415-441. Available from: 10.1016/S0263-8231(02)00009-5.

7) Zhou F, Xu W. Cyclic loading tests on concrete-filled double-skin (SHS outer and CHS inner) stainless steel tubular beam-columns. Engineering Structures. 2016;127:304-318. Available from: 10.1016/j.engstruct.2016.09.003.

8) Essopjee Y, Dundu M. Performance of concrete-filled double-skin circular tubes in compression. Composite Structures. 2015;133:1276-1283. Available from: https://dx.doi.org/10.1016/j.compstruct.2015.08.033.

9) Han LH, Huang H, Tao Z, Zhao XL. Concrete-filled double skin steel tubular (CFDST) beam-columns subjected to cyclic bending. Engineering Structures. 2006;28(12):1698-1714. Available from: https://dx.doi.org/10.1016/j.engstruct.2006.03.004.

10) Lu H, Han L, Zhao XL. Fire performance of self-consolidating concrete filled double skin steel tubular columns: experiments. Fire Safety Journal. 2010;45(2):106-111. Available from: 10.1016/j.firesaf.2009.12.001.

11) Huang F, Yu X, Chen B. The structural performance of axially loaded CFST columns under various loading conditions. Steel \& Composite structures. 2012;13:451-471. Available from: https://dx.doi.org/10.12989/scs.2012.13.5.451.

12) Haedir J, Zhao XL. Design of short CFRP-reinforced steel tubular columns. Journal of Constructional Steel Research. 2011;67(3):497-509. Available from: https://dx.doi.org/10.1016/j.jcsr.2010.09.005.

13) Han LH, Tao Z, Zhao XL. Behaviour of concrete-filled double skin (CHS inner and CHS outer) steel tubular stub columns and beam-columns. Journal of Constructional Steel Research. 2004;60(8):1129-1158. Available from: 10.1016/j.jcsr.2003.11.008.

14) Ramasubramani R, Aravind G, Koshika V, Kumar KKS, Chandra NE. Characteristic Study of Light Weight Aggregates and its Application in Concrete Filled Steel Tubes. ARPN Journal of Engineering and Applied Sciences. 2018;13(2):489-494. Available from: http://www.arpnjournals.org/jeas/research_ papers/rp_2018/jeas_0118_6694.pdf.

15) Ayyappa E, Roopa A. Experimental investigation on influence of brickbats and steel fibers in self compacting concrete. International Journal of Latest Engineering and Management Research. 2016;p. 807-814. Available from: http://www.ijlemr.com/papers/REETA2K16/EE084.pdf.

16) Singh R, Kaushik R, Singh G. Study of Self Compacting Concrete using Brick Dust and Marble powder. International Journal of Engineering Research and Applications. 2013;3(3):1283-1286. Available from: https://www.ijera.com/papers/Vol3_issue3/HI3312831286.pdf.

17) Apebo NS, Agunwamba JC, Ezeokonkwo JC. The suitability of crushed over burnt bricks as coarse aggregates for concrete. International Journal of Engineering Science and Innovative Technology. 2014;3(1):315-321. Available from: http://www.ijesit.com/Volume3/Issue1/IJESIT201401_39.pdf.

18) Nalanth N, Venkatesan PV, Ravikumar MS. Evaluation of the Fresh and Hardened Properties of Steel Fibre Reinforced Self-Compacting Concrete Using Recycled Aggregates as a Replacement Material. Advances in Civil Engineering. 2014;2014(6):1-6. Available from: https://dx.doi.org/10.1155/2014/671547.

19) Sekar T, Ganesan N, Nampoothiri NVN. Studies on strength characteristics on utilization of waste materials as coarse aggregate in concrete. International Journal of Engineering Science and Technology. 2011;3(7):5436-5440. Available from: https://www.ijest.info/docs/IJEST11-03-07-255.pdf.

20) Methods of physical tests for hydraulic cement. Bureau of Indian Standards. Available from: http://www.iitk.ac.in/ce/test/IS-codes/is.4031.4.1988.pdf.

21) Specification for Coarse and Fine Aggregates from Natural sources for concrete. Bureau of Indian Standards. 2002. Available from: https://www.iitk.ac. in/ce/test/IS-codes/is.383.1970.pdf.

22) Chang X, Luo XL, Zhu CX, Tang CN. Analysis of circular concrete-filled steel tube (CFT) support in high ground stress conditions. Tunnelling and Underground Space Technology. 2014;43:41-48. Available from: https://doi.org/10.1016/j.tust.2014.04.002.

23) Chitawadagi MV, Narasimhan MC, Kulkarni SM. Axial strength of circular concrete-filled steel tube columns - DOE approach. Journal of Constructional Steel Research. 2010;66(10):1248-1260. Available from: https://dx.doi.org/10.1016/j.jcsr.2010.04.006.

24) Methods of Tests for Strength of Concrete. Bureau of Indian Standards. 2004. Available from: https://www.iitk.ac.in/ce/test/IS-codes/is.516.1959.pdf. 
25) Pagoulatou M, Sheehan T, Dai XH, Lam D. Finite element analysis on the capacity of circular concrete-filled double-skin steel tubular (CFDST) stub columns. Engineering Structures. 2014;72:102-112. Available from: https://dx.doi.org/10.1016/j.engstruct.2014.04.039. 